Indonesian Journal of Theology 6/2 (December 2018): 204-226

\title{
UANG DAN KETERASINGAN
}

\author{
Nelman Asrianus Weny
}

\begin{abstract}
Money is, in of itself, an anonymous and neutral force. However, throughgoing capitalization in all dimensions of life has brought humankind to regard the making of money as its sole objective to be achieved by any means necessary. At the same time, the misuse of money breeds alienation. The expression, "Whosoever has the money, has the power," only exacerbates alienation. As a social reality, alienation presents a confessional challenge to the church, including churches in Indonesia. Adopting an interdisciplinary approach, with particular emphasis upon philosophical and theological studies, I argue that the church bears ethical-moral responsibility for overcoming this challenge. The solution that I offer amounts to a "new language" for money within the framework of a "theology of money": To meet its ministry obligations, the church needs money, yet the church must also combat the idolization of it. To wit, churches must dare to prove that each, whether as individual or institution, is truly free from all forms of monetary idolatry.
\end{abstract}

Keywords: money, anonymous force, idolatry, alienation, theology of money

\begin{abstract}
Abstrak
Uang adalah sebuah kekuatan anonim dan netral pada dirinya sendiri. Kendati demikian, kapitalisasi seluruh dimensi kehidupan menyebabkan manusia menjadikan uang sebagai satu-satunya yang harus dicapai meskipun dengan menghalalkan segala cara. Seiring dengan itu, keterasingan adalah salah satu dampak yang ditimbulkan oleh penyalahgunaan uang. Ungkapan "siapa yang memiliki uang, dialah yang berkuasa" makin menyuburkan keterasingan. Sebagai sebuah realitas sosial, keterasingan merupakan sebuah tantangan konfesional gereja, termasuk di dalamnya gereja-gereja di Indonesia. Berdasarkan kajian saya dari beragam perspektif, khususnya filosofis dan teologis, saya berpendapat bahwa gereja memikul tanggung jawab etis-moral untuk mengatasi tantangan ini. Solusi yang saya tawarkan
\end{abstract}


adalah sebuah "bahasa baru" bagi uang dalam kerangka "teologi uang." Gereja memang membutuhkan uang untuk memenuhi kebutuhan pelayanan namun yang harus dilawan oleh gereja adalah pemberhalaan uang. Artinya, gereja-gereja harus berani membuktikan bahwa ia, entah sebagai individu atau institusi, sungguh-sungguh bebas dari segala bentuk pemberhalaan uang.

Kata-kata Kunci: Uang, kekuatan anonim, pemberhalaan, keterasingan, teologi uang.

\section{Pendahuluan}

Tulisan ini dilandasi tesis "uang adalah sebuah kekuatan tanpa nama." Dengan tesis ini saya bermaksud menegaskan bahwa sebagai sebuah kekuatan tanpa nama uang tidak hanya menyatukan manusia dari berbagai kepentingan, namun serentak dengan itu, uang juga menciptakan keterasingan manusia dari dirinya dan sesamanya. Di dalam konteks penegasan di atas, saya mau memperlihatkan bahwa uang dan keterasingan adalah dua entitas yang saling berkaitan serta saling memberi dampak: Uang dapat dipakai untuk membeli kekuasaan, sebaliknya kekuasaan yang yang dimiliki seseorang berpotensi menciptakan keterasingan. Menurut saya, terdapat empat alasan bagi penegasan di atas. Pertama, pada prinsipnya uang adalah alat pembayaran yang sah. Manusia, baik secara individu maupun komunitas, membutuhkan uang. Kedua, kapitalisasi seluruh dimensi kehidupan manusia menyebabkan uang menjadi tujuan satu-satunya yang harus harus dicapai walaupun dengan menghalalkan segala cara. Ketiga, prinsip "siapa yang memiliki uang, dialah yang berkuasa" makin menyuburkan marginalisasi bahkan keterasingan antar-individu manusia. Keempat, jika gereja-gereja di Indonesia berkomitmen untuk memutus mata rantai keterasingan yang disebabkan oleh kekuatan uang, maka komitmen tersebut harus dimulai dengan sebuah praksis, yakni merekonstruksi sebuah "teologi uang" sebagai kekuatan yang secara simultan mengorientasikan praksis tersebut.

Supaya kita memperoleh gambaran awal sekaligus menyeluruh tentang isi artikel ini, saya membuat sistematika pembahasan sebagai berikut. Pertama, gagasan tentang uang dan problematikanya yang akan ditelaah dari perspektif filosofis. Kedua, relasi antara uang dan keterasingan. Ketiga, uang sebagai sebuah tantangan konfesional gereja. Keempat, masalah kita di Indonesia. Kelima, sebuah "bahasa baru" bagi uang. 


\section{Gagasan tentang Uang dan Problematikanya}

Gagasan tentang "uang" setidaknya berawal dari Aristoteles (384-322 SZB), seorang filsuf Yunani Kuno, yang mengemukakan alasan bagi kemunculan uang yakni ketidakpraktisan sistem barter. Berdasarkan alasan inilah uang diciptakan, mulai dari bentuk yang paling sederhana (koin) berbentuk emas, perak, dan kuningan, hingga uang kertas bahkan kini dalam bentuk surat-surat berharga seperti giro, cek, kartu debit, dan kartu kredit. ${ }^{1}$ Fungsi utama uang menurut Aristoteles adalah bukan saja sebagai alat pertukaran tetapi juga memiliki fungsi derivatif, yakni sebagai ukuran nilai. Meskipun definisi ini masih diperdebatkan, namun ekonom klasik Adam Smith dalam karya klasiknya An Inquiry into the Nature and Causes of the Wealth of Nations (1776), yang mengikuti David Ricardo tentang "uang sebagai nilai" (1752), meletakkan dasar-dasar ekonomi modern. Smith menegaskan kembali ortodoksi Aristotelian untuk melawan kaum merkantilis Eropa (seperti Victor de Riqueti dan Maquis de Mirabeau di abad ke16 hingga 18), yang memandang fungsi utama uang sebagai penyimpan nilai. ${ }^{2}$ Bahkan, Georg Friedrich Knapp (1905), dengan teorinya tentang "uang negara," menegaskan bahwa fungsi utama dari uang adalah alat pembayaran serta divalidasi oleh statusnya sebagai tender legal. Deskripsi singkat di atas mengisyaratkan bahwa para ekonom klasik belum menyadari uang sebagai sebuah fakta sosial. ${ }^{3}$

Ilmuwan sosial yang secara sistematis melawan konsep ortodoks tentang uang adalah Karl Marx (1818-1883). Menurutnya, fungsi utama uang terletak pada perannya sebagai "bentuk nilai independen dan kapital." Dengan definisi ini, Marx menegaskan bahwa karena uang merupakan instrumen kapitalisme dan kaum kapitalis yang dicirikan oleh eksploitasi dan dominasi, maka uang pada dirinya sendiri bersifat "netral secara sosial.",

Sebuah kontribusi sosiologis paling penting bagi teori uang datang dari Georg Simmel. Dalam karya klasiknya Philosophy of Money (1900), Simmel mengajukan pembahasan yang sangat brilian tentang pengaruh uang di dalam masyarakat. Menurutnya, irasionalitas dari sebuah masyarakat yang didominasi oleh uang, justru direlatifkan pada metafisika universal sebagai proses psikologis yang dengannya sarana

\footnotetext{
1 William Outhwaite, ed., Kamus Lengkap Pemikiran Sosial Modern (Jakarta: Kencana, 2008), 533.

2 John Kenneth Galbraith, Money (Boston: Houghton Mifflin, 1976).

3 Outhwaite, Kamus Lengkap Pemikiran Sosial Modern, 533-534.

${ }^{4}$ Karl Marx, Kapital: Buku 3 Proses Produksi Kapitalis Secara Menyeluruh, trans., Oey Hay Djoen (Bandung: Hasta Mitra, 2007), 822-828. Michael Hardt and Antonio Negri, Empire (Cambridge: Harvard University Press, 2001), 234-237.
} 
dan tujuan masyarakat itu diputarbalikkan. Jadi, ciri paling esensial dari suatu masyarakat kapitalis sebagai alat kapital menurut Marx, direlatifkan Simmel kepada proses psikologis misterius karena memang uang didesain sebagai sebuah instrumen nalar. Lebih tegasnya ia mengatakan, ${ }^{5}$

[M]oney is simply a means, a material or an example for the presentation of relations that exist between the most superficial, "realistic," and fortuitous phenomenon and the most idealized powers of existence, the most profound currents of individual life and history... money as a practical phenomenon more intensively than any other discipline, no object can sufficiently be examined in one discipline only. Money goes everywhere and is exchanged with something else... Money more and more the expression and equivalent of all values, above all objects it become the center in wich the most estranged and distant thoughts meet up one another.

Kutipan ini menegaskan posisi Simmel yang sama sekali tidak bermaksud mengatakan bahwa munculnya ekonomi berbasis uang itu disebabkan oleh modernitas akan tetapi melihat sebuah sistem berbasis uang sebagai bentuk modern aktivitas perekonomian kontemporer yakni, hubungan kausal antara uang dan perilaku sosial keseharian. Itulah sebabnya Simmel memaknai uang sebagai sesuatu yang muncul dalam struktur perilaku manusia yang lebih mementingkan tujuan dan di dalam hasrat mengejar tujuan akhir melalui seperangkat tindakan instrumental. Uang, kata Simmel, menerobos ke dalam jaringan teleologis antara ketamakan dan pemenuhannya, dalam proses meminta maupun memaksakan keinginan pribadi. Kepada manusia, uang juga memberi hak untuk membeli, hak untuk memiliki, bahkan hak untuk menguasai semata-mata demi memuaskan keinginan manusia. ${ }^{6}$

Alaiene Deneault, yang dikutip oleh David Kim, mengaitkan karya Simmel dengan The Interpretation of Dreams karya Sigmund Freud sebagai "estetika-estetika teologis" dari ekonomi. Dalam pandangan Deneault, uang, dalam bentuknya yang indrawi, tidak sama dengan Allah yang tidak kelihatan. Akan tetapi, (seperti Allah) uang adalah sebuah ilusi, yang secara puitis dan naratif, berpengaruh pada perilaku keseharian dan keyakinan bersama. Pernyataan Deneault bahwa "uang dan Allah adalah dua entitas terpisah yang otonom," memberi kesan

\footnotetext{
${ }^{5}$ Georg Simmel, The Philosophy of Money, trans., David Frisby (New York: Routledge, 2004), 117-131, 133-134.

${ }^{6}$ Ibid., $283 \mathrm{ff}$.
} 
yang kuat bahwa menerima keduanya (uang dan Allah) secara serentak merupakan akar dari diversitas dan distansi antar-manusia dengan "pandangan tunggal yang tumpang-tindih," yakni di dalam uang dan Allah, ada ketenangan dan masa depan — Sicherheit und Ruhe.

Uraian di atas memperlihatkan bahwa kendati ada perbedaan dalam spesifikasi fungsi dan hubungan hirarkis namun ada juga kesamaannya. Selain mengabaikan uang sebagai sebuah problematika sosial, juga dalam menegaskan kesimetrisan relasi pertukaran (exchange) sebagai basis rasionalitas instrumental dari uang, teori-teori ini justru mengabaikan kesimetrisan esensial di dalam relasi dominasi (penguasaan) yang dengannya uang menegaskan dirinya "bukan sebagai sekadar simbol namun kekuatan sosial yang otonom." Konsekuensinya adalah relasi-relasi antar-individu, antar-keluarga, dan antar-bangsa dalam masyarakat semakin ditentukan oleh uang. Model relasi seperti ini bahkan menjadi tipe kekuasaan baru dalam budaya modern. Uang sebagai "penguasa baru" memengaruhi bahkan menghancurkan seluruh pranata sosial, politik, ekonomi, hukum bahkan agama. ${ }^{9}$

Dari perspektif penegasan di atas dapat dikatakan bahwa, uang menjadi basis bagi sebuah masyarakat kapitalis yang di dalamnya terdapat jurang pemisah antara kebutuhan individu dan kebutuhan masyarakat kapitalis. Dalam konteks inilah, uang telah dijadikan sebagai alat untuk mendefinisikan posisi individu dalam masyarakat bahkan menjadi sarana penciptaan disparitas antar-individu dan antarkomunitas. Itulah sebabnya tidak mengherankan apabila dalam kenyataan seorang pemakai uang secara sadar dan sengaja (sistemik) menciptakan kesenjangan dalam distribusi kesejahteraan individual. ${ }^{10}$ Dalam masyarakat industrial, majikan adalah pemilik uang sedangkan nilai diri seorang buruh berdasarkan pada berapa jumlah uang yang diperoleh. Pola serupa berlaku juga di dalam sebuah masyarakat hirarkis. Orang yang tidak memiliki uang harus bekerja pada orang lain yang memiliki uang. Antara kedua pihak terdapat jarak hirarkis yang sangat lebar. Pekerja sama sekali tidak terkait dengan sarana-sarana produksi karena mereka dihargai bukan hanya sebatas nilai nominal

7 Richard Rorty, Philosophy and Social Hope (London: Penguin Books, 1999), 223-228. David Kim, ed., Georg Simmel in Translation (Cambridge: Cambridge Scholar Press, 2006), 15.

${ }^{8}$ Lihat juga Outhwaite, Kamus Lengkap Pemikiran Sosial Modern, 533-538.

9 T.R Thoren and R.F. Warner, Truth in Money (Ohio: Chagrin Falls, 1999). Joel Kurtzman, The Death of Money (New York: Simon and Schuster, 1993).

10 William F Hixon, It's Your Money (Toronto: COMER, 1997), $1 \mathrm{ff}$. 
uang, tetapi sekaligus sebagai "mesin" yang memroduksi laba bagi sang pemilik kapital. ${ }^{11}$

\section{Uang dan Keterasingan}

Keterasingan (estrangement) menunjuk kepada "keadaan terpinggirkan" dari segi substansi dan implikasinya. Richard Schacht adalah penulis yang cukup berhasil merangkum pemikiran para filsuf tentang keterasingan sebagai "perampasan hak-hak pribadi."12 Merujuk pada latar belakang linguistik serta pemikiran para filsuf dan kritikus sebelum dan sezaman G.F.W. Hegel, Karl Marx, Erick Fromm, dan Karen Horney, Schacht memetakan beberapa jenis keterasingan, yakni keterasingan dari diri sendiri, keterasingan dari pekerjaan, keterasingan dari sesama, dan keterasingan dari budaya. ${ }^{13}$

Hubungan antara uang dan keterasingan ditemukan di dalam karya klasik Marx, Das Kapital. Bagi Marx, tanda dan penyebab utama dari keterasingan adalah uang. Demi uang manusia tidak lagi bertindak demi sesuatu yang bernilai atau demi melayani kebutuhan sesama. Seluruh tindakan manusia adalah demi memperoleh uang. Segala sesuatu dilihat dan diukur dari nilai uang. ${ }^{14}$ Dalam kata-kata Marx yang dikutip oleh Franz Magnis-Suseno dijelaskan bahwa ${ }^{15}$

yang penting nilai uangnya, bukan barang ("alam") itu sendiri. Begitu pula, meskipun orang lain lapar, tetapi apabila ia tidak memiliki uang saya tidak akan memberikan makanan kepadanya...sebaliknya, asal saya memiliki uang, biarpun saya tidak lapar, saya dapat memperoleh makanan sebanyak yang saya kehendaki. Keterasingan dari manusia lain terlihat dalam fakta bahwa kebutuhannya tidak lagi mendesak saya untuk memenuhinya meskipun saya mampu. Sikap saya seluruhnya

11 Jacques Ellul, Money and Power, trans., LaVonne Neff (Downers Grove, Illinois: InterVarsity Press, 1984), 357ff. Lihat juga Max Weber, The Protestant Ethics and the Spirit of Capitalism, trans., Talcot Parsons (London: Routledge, 1996), 47-57.

12 Istilah "keterasingan" berasal dari bahasa Inggris alienation/estrangement dan bahasa Jerman, entfremdung: "mengalienasi, merampas, mengambil, mencabut." Richard Schacht, Alienasi: Pengantar Paling Komprehensif, trans., Ikramullyah Mahyuddin (Bandung: Jalasutra, 2005), 11-18.

13 Ibid., 49.

14 Marx, Kapital: Buku 3, 822-828.

15 Franz Magnis-Suseno, Pemikiran Karl Marx: Dari Sosialisme Utopis Ke Perselisihan Revisionisme (Jakarta: Gramedia, 2003), 98-99. Karl Marx, Kapital: Buku 1 Proses Produksi Kapital, trans., Oey Hay Djoen (Bandung: Hasta Mitra, 2004), 591-615. Karl Marx, Kapital: Buku 2 Proses Sirkulasi Kapital, trans., Oey Hay Djoen (Bandung: Hasta Mitra, 2007), 109. 
egois. Saya hanya akan memenuhi kebutuhan orang lain sejauh saya sendiri memperoleh keuntungan darinya.

Uang, seperti emas, demikian dikutip Marx dari William Shakespare (Timon of Athens) dan Göthe (Faust), "membuat hitam menjadi putih, bodoh menjadi pandai, keliru menjadi benar, hina menjadi terhormat, tua menjadi muda, dan pengecut menjadi pemberani."16

Di dalam konteks pernyataan Shakespare ini, Marx membuat lima klaim pembedaan namun saling terkait. Pertama, uang meruntuhkan dan mengubah segala sesuatu yang disentuh olehnya. Ia mengkomodifikasi, mentransformasi, dan mendegradasi seluruh hubungan antar-manusia. Kedua, uang mengkorosi segala sesuatu, entah cepat atau lambat; segala sesuatu termasuk manusia akan dihargai berdasarkan uang. Ketiga, uang mengubah semua kualitas alami manusia menjadi kebalikannya. Pernyataan ini sangat logis karena dalam sebuah masyarakat (kapitalis) segala sesuatu niscaya bagi orang yang memiliki uang, sedangkan bagi mereka yang tidak memiliki uang hidup adalah perjuangan yang mahaberat. Kebutuhan tanpa uang tidak akan pernah terpuaskan, namun kebodohan yang didukung oleh kekuatan uang mendorong pemilik uang berbuat sekehendak hatinya. Keempat, alienasi bahkan telah menginfeksi bahasa kita. Dalam katakata Marx sendiri, "kebutuhan sebagai hak asasi individu, dirusakkan oleh uang... 'bahasa' kebutuhan dinistakan oleh uang." Konsekuensinya adalah menjadi sesuatu yang memalukan untuk meminta sesuatu berdasarkan kebutuhan. Kita harus mengiba-iba atau merengek-rengek terlebih dahulu. Kelima, antitesis dari keterasingan adalah cinta kasih antara laki-laki dan perempuan sebagai "hubungan langsung, alami, niscaya, dan hubungan antar-manusia." Dalam cinta sejati ini ada kesediaan saling untuk memenuhi kebutuhan tanpa melirik pada keuntungan egoisnya sendiri. ${ }^{17}$

\section{Perspektif Teologis}

Korelasi antara uang dan kekuasaan dalam penciptaan keterasingan ditemukan di dalam karya klasik Jacques Ellul, Money and

${ }^{16}$ Jonathan Wolff, Mengapa Masih Relevan Membaca Marx Hari Ini?, trans., Yudhi Santosa (Jakarta: Gramedia, 2004), 33.

17 Magnis-Suseno, Pemikiran Karl Marx, 99. Bdk, Virginia Burrus and Catherine Keller, eds., Toward a Theology of Eros (New York: Fordham University Press, 2006). Mario Costa, "For the Love of God: The Death of Desire and the Gift of Life," in Toward a Theology of Eros, eds., Virgina Burrus and Catherine Keller (New York: Fordham University Press, 2006), 38-62. Lihat juga Karol Wojtyla, Love and Responsibility, trans., H.T. Willetts (London: William Collins Son \& Co. Ltd., 1981), 73-100. 
Power (1984). ${ }^{18}$ “Siapa memiliki uang dialah yang berkuasa!" demikian ungkap Ellul. Uang dan kekuasaan menjadi sangat esensial dan orang Kristen berada dalam sekaligus menjadi bagian dari sebuah dunia yang dicirikan oleh pengejaran akan sukses finansial. Karena itulah seluruh pandangan, sikap, dan perilaku terhadap uang haruslah dibentuk serta diorientasikan tidak hanya oleh prinsip-prinsip ekonomi tetapi juga (terutama) oleh prinsip-prinsip biblis dan etis-teologis. ${ }^{19}$

Menurut Ellul, kesalahan fatal yang terus terjadi adalah bahwa ketika berbicara tentang uang, kita lebih cenderung memahaminya dari perspektif masyarakat yang di dalamnya kita hidup yakni perspektif ekonomi. Akibatnya, gagasan tentang uang kemudian menjadi amat kompleks karena terselubung di dalam slogan-slogan entah kesejahteraan atau kemakmuran. Dari perspektif inilah Ellul menegaskan bahwa uang berkait erat dan berefek timbal-balik dengan fenomena ekonomi. Itulah sebabnya dalam realitas, uang menjadi simbol dari sistem dan perilaku ekonomi. Pada satu sisi, uang sebagai ukuran nilai, nilai distribusi, bahkan kapitalisasi kemakmuran, ia memiliki fungsi ekonomis yang definitif. Namun pada lain sisi, yakni dalam pengertian yang lebih luas, uang tidak bernilai di luar sistem dan perilaku ekonomi yang dilegitimasi oleh sebuah otoritas politis. Dengan demikian, baik uang maupun berbagai persoalan yang terkait dengannya juga menjadi abstrak dan impersonal. Ellul menjelaskan hal itu bersifat ${ }^{20}$

Abstrak karena seseorang (individu) tidak menggenggam sesuatu yang bernilai di dalam dirinya sendiri; ia tidak dapat menyematkan makna yang pasti pada uang yang digunakan. Koin, sama dengan uang kertas, menjadi simbol-simbol abstrak....Simbol itu sendiri, seperti realitas ekonomi yang oleh karenanya uang hadir di sana, bahkan menjadi lebih abstrak. Impersonal karena, tidak seperti penggunanya, uang bukanlah sebuah tindakan aktual, uang tidak dapat dikontrol secara personal kecuali sebagai hasil interaksi berjarak dan kompleks.

Karena tidak adanya relasi konkret antara individu dan uangnya, sehingga dimensi etis-moral tidak memperoleh tempat. Bahkan dimensi moral dan persoalan-persoalan individual disubordinasi kepada persoalan kolektif dan sistem ekonomi secara total. ${ }^{21}$

\footnotetext{
18 Ellul, Money and Power.

${ }^{19}$ Ibid., 5-8.

20 Ibid., 10.

${ }^{21}$ Lihat juga Weber, The Protestant Ethics and the Spirit of Capitalism, 48-50.
} 
Dengan mengakui keabstrakan dan impersonalitas uang, Ellul akhirnya tiba pada pertanyaan: bagaimana uang didistribusikan? Pertanyaan krusial ini dilandasi argumen bahwa tindakan individu hanyalah menerima atau membayar, tidak di dalam distribusi. Itulah sebabnya, problematika uang bukan sekadar individual tetapi juga korporasional seperti dipraktikkan kapitalisme, kolektivisme, sosialisme, dan komunisme. Bahkan jika persoalan ini dikaji serta mencoba menjawabnya dari perspektif ekonomi global, maka masalah utamanya adalah "uang" yang terkait bagaimana individu mengorganisir uang di dalam kerangka sistem ekonomi korporasional. Artinya, semua sikap individual kita bergantung pada cara menyelesaikan persoalan yang disebabkan uang. ${ }^{22}$

Kedua problematika (individual dan korporasional) ini dikarenakan kesalahan, kemunafikan, dan ketidakberanian dalam pendekatan sistemik terhadap uang. Disebut "kesalahan pendekatan sistemik," lantaran menafikan kedudukan manusia yang bahkan lebih tinggi daripada uang. Konsekuensinya adalah manusia diposisikan bukan sebagai subjek atas uang, melainkan sebagai objek yang nilai dirinya ditentukan oleh uang. Hampir di dalam semua kasus, hakikat manusia (dengan hasrat untuk memperoleh uang) dianggap merusak sistem, dan oleh karenanya, para penganut model pendekatan ini mengklaim bahkan yakin bahwa persoalan uang bisa diselesaikan hanya dengan sebuah sistem. ${ }^{23}$

Terlepas dari entah adanya perbedaan mencolok atau adanya sedikit kemiripan antara kedua problematika (individual dan korporasional) ini, uang tetap memainkan peran sentral karena ia memiliki fungsi praktis dalam pengukuran nilai, sirkulasi, dan kapitalisasi (walaupun tidak individual). Uang, dalam posisi dan peran seperti ini, menjadi simbol sekaligus instrumen kekuasaan politik dan ekonomi transaksional, baik personal maupun komunal. Implikasinya adalah bahwa sesempurna apa pun sebuah sistem dibangun, namun jika menafikan eksistensi dan martabat manusia maka sistem itu sebenarnya memperbudak bahkan membutakan individu dengan seluruh kemungkinan politis dan psikologis yang memaksa melalui kebijakan, kerja, propaganda, dan penyebarluasan ketakutan.

Berkenaan dengan sikap kekristenan, menurut Ellul, memang terdapat kesulitan, bahkan kecil kemungkinan merumuskan sebuah doktrin Kristen tentang uang. Kendati demikian ia mengusulkan dua argumen yakni argumen ekonomi dan argumen moral. Ketika kita berbicara tentang uang dalam masyarakat, kita membicarakannya dalam istilah-istilah ekonomi, namun ketika membicarakan masalah

\footnotetext{
22 Ellul, Money and Power, 9-11.

23 Ibid., 12-13.
} 
yang ditimbulkannya dalam kehidupan individu, kita harus mempertanyakan sebab-musababnya di dalam istilah-istilah moral. Artinya, tegas Ellul, gereja bahkan setiap orang Kristen harus berbicara tentang uang tidak saja karena uang memainkan peran sentral di dalam masyarakat, tetapi juga (terutama) karena Alkitab menegaskan secara spesifik: uang sebagai "berkat Allah." Uang di dalam dirinya sendiri bernilai spritual namun serentak dengan itu uang adalah "godaan," oleh karenanya mencintai (memberhalakan) uang, seperti yang diingatkan oleh Paulus, adalah "akar dari segala jenis kejahatan" (1Ti. 6: 10). ${ }^{24}$

Tentang uang sebagai berkat Allah sekaligus godaan, Ellul mengingatkan kembali bahwa Alkitab memang sama sekali tidak bersikap antipati terhadap uang, termasuk di dalamnya kekayaan atau kemakmuran. Alkitab bahkan berkali-kali menegaskan bahwa Allah adalah sumber segala berkat dan bahwa berkat itu diberikan kepada setiap orang sebagai konsekuensi dari ketaatan kepada-Nya. Sejumlah tokoh, khususnya Abraham, Ayub, dan Salomo (Kej. 12-14: 22-24; Ayb. 1: 1-4; 42: 7-17; 2Ra. 10: 14-29; 2Ta. 9), adalah orang-orang yang berkenan bagi Allah untuk menikmati kekayaan, kekuasaan, dan kejayaan-Nya. Namun serentak dengan itu, Abraham, Ayub, dan Salomo (beserta keluarga) juga jatuh ke dalam dosa karena tidak mampu mengalahkan godaan kekayaan, kekuasaan, dan kejayaan itu (Kej. 16: 1-16; 21: 8-21; 1Ra. 11; Ayb. 1: 5-2: 13).

Kisah-kisah ini menjelaskan bagi kita bahwa cara pandang Alkitab memang berbeda dari cara pandang dunia modern. Di dalam Alkitab, uang lebih jarang disebut sebagai "objek netral," artinya tidak otonom atau objek yang menghasilkan diri sendiri, apalagi dari titikpandang moneter. Itulah sebabnya ketika muncul pertanyaan, "siapakah sesungguhnya pemilik uang?" kita hanya boleh berasumsi bahwa pemiliknya adalah Allah (Hag. 2: 8). Masalah kepemilikan ini menjadi makin krusial jika ditelaah dalam spektrum pertanyaan Yesus tentang simbol-simbol moneter: "gambar dan tulisan siapakah ini?" (Mat. 22: 20). Beberapa inskripsi menginformasikan konsep kepemilikan ini, bahkan Yesus secara eksplisit menunjuk kepada pribadi Kaisar Roma sebagai simbol kekuasaan politik dan negara, tercakup di dalamnya simbol-simbol kekuasaan ekonomi dan moneter kontemporer. $^{25}$

Meskipun demikian, masalah kepemilikan uang bukanlah inti dari pertanyaan Yesus melainkan penggunaan istilah "Mamon" (Mat.

24 Ibid., 73.

25 Ibid., 16-17, 73-90. H.St.J. Hart, 'The Coin of 'Render Unto Caesar...' (a Note on Some Aspects of Mark. 12:13-17; Matt. 22:15-22; Luk. 20:20-26)," in Jesus and the Politics of His Day, eds., Ernst Bammel and C.F.D. Moule (Cambridge: Cambridge University Press, 1988), 241-248. 
6: 24; Luk. 16: 13) yang menunjuk kepada "uang" dan "kemakmuran material." Tentunya Yesus tidak mengadopsi sebutan yang populer di kalangan para pendengar-Nya (entah orang Yahudi, Galilea atau nonYahudi). Namun dengan penyebutan ini Yesus hendak menegaskan bahwa Mamon adalah salah satu dari sejumlah kekuatan dunia yang menimbulkan kehancuran dan kebinasaan. Dengan kata lain, Mamon adalah gagasan tentang sebuah "kekuasaan," bukan personifikasi uang pada dirinya sendiri. ${ }^{26}$

Bagi Yesus, demikian interpretasi F.F. Bruce, uang adalah wujud dari kekuasaan bukan dalam makna yang terselubung sebagai kekuatan (force), melainkan dalam makna spesifiknya dengan tiga karakter. Pertama, sebagai sesuatu yang dapat bertindak demi, atas nama, dan dengan dirinya sendiri; ia sanggup menggerakkan segala sesuatu di luar dirinya, menjadi otonom, melampaui hukum yang mengaturnya, sanggup menghadirkan dirinya sendiri sebagai agen aktif. Kedua, sebagai kekuasaan, uang dalam artian Mamon memiliki nilai spiritual. Itulah sebabnya kekuasaan (Mamon) tidak pernah netral tetapi selalu berorientasi dan diorientasikan kepada manusia. Ketiga, uang adalah kekuasaan bukan hanya lantaran manusia menggunakannya tetapi juga ketika kekuatan spiritual Mamon itu menjadikan manusia serakah untuk menumpuk uang dan kekayaan bagi diri sendiri. Dengan demikian kekuatan spiritual Mamon memungkinkan manusia memberi karakteristik "sakral" kepada uang, oleh karenanya ia diberhalakan. ${ }^{27}$

Pemberhalaan uang dapat dilihat melalui pengaruhnya dalam tipe-tipe tertentu dan spesifik dari relasi, sikap, dan perilaku antarmanusia, yakni relasi jual-beli. Segala sesuatu di dalam dunia bisa diperjualbelikan dengan uang, tidak terkecuali manusia dengan seluruh eksistensinya (1Ra. 21: 1-19; Ams. 2: 6; 8: 6), keadilan hukum bahkan keselamatan (Amo. 5: 7-13 dan 21-23) dan anugerah Allah (2Ra. 5: 1526; Kis. 8: 18-20). Kasus terkait yang menjelaskan kekuasaan destruktif uang adalah "berkhianat demi uang." Pengkhianatan Yudas terhadap Yesus adalah contoh konkret dari ketamakan atau nafsu menguasai, kebencian, dan kekerasan (Mat. 26: 14-16; Mrk. 14: 10-11; Luk. 22: 36). Itulah sebabnya setiap perlawanan terhadap korupsi dan jual-beli

${ }^{26}$ Lihat juga antara lain Conrad Boerma, Dapatkah Orang Kaya Masuk Sorga?, trans., F.K.N. Harahap (Jakarta: BPK Gunung Mulia, 1999). Bas de Gaay Fortman dan Berma Klein Goldenwijk, Allah dan Harta Benda, trans., Bambang Subandrijo (Jakarta: BPK Gunung Mulia, 2001).

${ }^{27}$ F.F Bruce, "Render to Caesar," in Jesus and the Politics of His Day, eds., Ernst Bammel and C.F.D. Moule (Cambridge: Cambridge University Press, 1988), 249-264. Richard A Horsley, Jesus and the Spiral of Violence (Minneapolis: Fortress Press, 1993), 306-317. Garry Wills, What Jesus Meant: Maksud Yesus Yang Sebenarnya, trans., Semuel O. Aitonam (Jakarta: Gramedia Pustaka Utama, 2007), 44-49. 
keadilan oleh para nabi PL bahkan pengusiran Yesus terhadap para penukar uang, baik di dalam maupun di pelataran Bait Allah, merupakan wujud perlawanan Yesus terhadap supremasi uang (Mat. 21: 12-13; Mrk. 11:15-17; Luk. 19:45-46; Yoh. 2:13-35). ${ }^{28}$

Jika Ellul berbicara tentang uang dan kekuasaan sebagai dua entitas yang saling memberi makna, maka relasi problematis tersebut dipahaminya di dalam konteks dunia manusia yang menurutnya telah dikendalikan oleh Mamon. Terkait ini saya mengacu pada konsep terminologi "Dunia Mamon" sebagai frase stenografis yang dipergunakan William Schweiker untuk memberi interpretasi teologisetis kepada situasi ekonomi kekinian. ${ }^{29}$ Secara sistematis, gagasan tentang "dunia" menghubungkan sebuah klaim deskriptif (masyarakat manusia yang membutuhkan stabilitas dan tatanan) dengan gagasan biblis mengenai penciptaan, dosa, penebusan, dan eskatologi. Sementara itu, "Mamon" adalah istilah berbahasa Aram (dari akar kata $m n$ : diakrabi atau dipercaya) yang menunjuk kepada kemakmuran dan kekayaan. Di satu pihak, Mamon dipandang sebagai "yang menentramkan, menjaminkan kenyamanan dan keamanan, sehingga padanya seseorang memercayakan seluruh kehidupan dan masa depannya." 30 Di lain pihak, Mamon adalah basis ancaman bagi kehidupan moral, religius, dan sosial yang berpersonifikasi sebagai ketamakan, membangkitkan kekaguman dan disembah namun serentak dengan itu, memperbudak. Akar dari paradoks ini tidak dalam sistem atau segala yang dibuat manusia tetapi dari dalam diri manusia. Terhadap ketamakan inilah, Yesus menyatakan: "kamu tidak dapat mengabdi kepada Allah dan Mamon" (Mat. 6: 24; Luk. 16: 13). Sikap Yesus ini tentu saja berlawanan dengan cara berpikir saat itu. Skala prioritas Yesus bukan uang dan harta melainkan Allah: Dahulukan Allah dan uang akan mengurus dirinya sendiri, atau lebih tepat, Allah yang akan mengurusnya (Mat. 6: 33). Artinya, jika Allah didahulukan maka Ia akan memengaruhi cara kita dalam memaknai dan menggunakan uang. Di dalam spektrum yang sama, ungkapan "mencintai uang adalah akar segala kejahatan" sebagai tema

${ }^{28}$ Ellul, Money and Power, 25-30, 90-116. Lihat juga Walter E Pilgrim, Good News to the Poor (Minneapolis, Minnesota: Augsburg Publishing House, 1981), 105122, bdk. 47-159.

${ }_{29}$ William Schweiker, "Responsibility in the World of Mammon," in God and Globalization 1, eds., Max L. Stackhouse \& Peter J. Paris (Harrisburg: Trinity International Press, 2000), 109-110.

30 Rorty, Philosophy and Social Hope, $223 \mathrm{ff}$. 
fundamental Alkitab, memperoleh makna dan signifikansinya (1Ti. 6: 10; 2Ti. 3: 2). ${ }^{31}$

\section{Keterasingan sebagai Tantangan Konfesional Gereja}

Paul J. Tillich (1886-1965) tidak secara spesifik menyebut uang sebagai penyebab dari keterasingan. Bagi Tillich, keterasingan adalah nama lain dari dosa, yakni ketika "eksistensi diasingkan dari esensi...keterasingan manusia dari wujud esensialnya adalah karakter universal dari ekistensi." Menurutnya, terdapat tiga tanda keterasingan: ketidakpercayaan (unbelief), hasrat yang kuat (concupiscence), dan kebanggaan yang berlebihan (bubris). ${ }^{32}$ Signifikansi konsep "keterasingan" dalam pemikiran Tillich dapat dilihat dari argumennya: keterasingan definitif terhadap eksistensi manusia. Status eksistensi adalah status keterasingan. Ketika manusia bereksistensi, ia bukan merupakan diri esensialnya sendiri. Manusia teralienasi dari wujud sejatinya. Ia mengklaim bahwa keterasingan adalah "pertanyaan" mendasar yang berkaitan dengan situasi manusia. ${ }^{33}$

Di era ketamakan ini, kenyataan yang tidak bisa dipungkiri adalah bahwa uang disembah sebagai "kebaikan tertinggi" (summum bonum). Seluruh pikiran dan perilaku manusia dipenuhi hanya dengan usaha mengejar dan mengakumulasi uang sebagai tujuan akhir satusatunya dari seluruh kehidupan manusia. Tidak berlebihan jika Ulrich Duchrow, yang merujuk pada Karl-Heinz Brodbeck, menegaskan bahwa "uang sudah menguniversalkan cara berpikir kita bahkan menciptakan sebuah kerangka kerja yang dengannya seluruh aktivitas di dalam kehidupan ini dikalkulasi." 34

Gagasan Duchrow ini hampir senada dengan pernyataan Michael Hardt dan Antonio Negri bahwa di era kedaulatan kapitalisme ini, uang mengokohkan posisi dan perannya sebagai sebuah empire melampaui kekuatan nuklir dan media, serta memiliki kapasitas absolut untuk menghancurkan seluruh dimensi kehidupan manusia. Di dalam kapasitas seperti inilah, uang mengkonstruksi pasar dunia dengan lebih dahulu mendekonstruksi pasar-pasar lokal, menghancurkan otoritas moneter nasional, dan mensubordinasinya kepada sekadar "para

31 Ellul, Money and Power, 117. Lihat juga R.T. France, Yesus Sang Radikal: Potret Manusia Yang Disalibkan, trans., P.G. Katoppo (Jakarta: BPK Gunung Mulia, 2004), 81-85.

32 Paul J. Tillich, Systematic Theology 2 (Chicago: University of Chicago Press, 1957), 30, 74. Schacht, Alienasi, 274.

33 Tillich, Systematic Theology 2, 44-45. Schacht, Alienasi, 275.

34 Martin Sinaga, ed., A Common Word: Buddhists and Christians Engage Structural Greed (Minneapolis: Lutheran University Press, 2012), 12. 
peminta belas kasihan" dari pemilik otoritas keuangan global. ${ }^{35}$ Pernyataan ini sangat logis karena uang, sebagaimana ditegaskan oleh F. Hinkelammert, adalah "akar dari pemberhalaan pasar, kapital, dan komoditi." Dengan demikian, kata Hinkelammert, ungkapan klasik Thomas Hobbes bahwa, "kendati uang tidak berdarah namun kalau dialirkan ke dalam dunia industri akan melahirkan kehidupan baru, yakni pasar," mendapatkan aktualitas dan pembenarannya. ${ }^{36}$

Di dalam konteks kekinian, secara sangat dramatis uang membentuk sebuah pemahaman diri manusia baik individual maupun komunal. Artinya, orang yang tidak memiliki uang akan memahami dirinya "tidak bernilai/berharga," sebaliknya memiliki uang berarti memiliki nilai/harga diri. Supaya memiliki harga diri, orang akan tanpa malu menghalalkan berbagai cara seperti penipuan, korupsi, perampokan, dan pemerasan. Dengan kata lain, "uang" yang adalah salah satu kosa kata (bahasa) ekonomi, kini menjadi sarana reproduksi kultural sekaligus memberikan sebuah label atau identitas kultural baru bagi masyarakat global, yakni ketamakan. Konstruksi identitas semacam ini merupakan sebuah kekuatan yang berdampak mematikan karena berlawanan dengan nilai kemanusiaan bahkan nilai-nilai kehidupan itu sendiri. Supremasi uang sungguh-sungguh merusak semua tatanan atau nilai, bahkan perilaku etis-religius, yakni membuat segala sesuatu permisif (serba boleh). Celakanya, kerusakan ini dianggap "wajar." 37

Kamran Mofid, teolog Katolik berkebangsaan Iran, menyebut tugas gereja dalam memerangi kekuasaan Mamon sebagai ziarah iman dari "tanah gersang ke tanah yang dijanjikan." Menurutnya, ${ }^{38}$

"tanah gersang" adalah lokasi pemenjaraan kaum miskin, lemah, dan rapuh; para pengangur dan yang termajinalkan, mereka yang hak-hak sosial dan ekonominya dieksploitasi secara semena-mena oleh para pemilik uang (kapital). Tanah gersang adalah "ladang pembantaian" nilai kemanusiaan, tempat bertumbuh suburnya individualisme, egoisme, dan pamer kekuasaan serta kekayaan dari para konglomerat. Tanah gersang adalah tanah tanpa solidaritas, tanpa keadilan, tanpa

${ }^{35}$ Hardt, Empire, 345-346.

${ }^{36}$ Franz Hinkelammert, "The Economic Roots of Idolatry," in The Idols of Death and the God of Life, ed., Pablo Richard (Maryknoll: Orbis Books, 1983), 165-183. Bdk. Jürgen Moltmann, God for a Secular Society: The Public Relevance of Theology, trans., M. Kohl (London: SCM Press, 1999).

37 Schweiker, "Responsibility in the World of Mammon," 124-125.

38 Kamran Mofid, Globalisation for Common Good (London: ShepheardWalwyn, 2001), 15ff. Lihat juga Ulrich Duchrow, Global Economy: A Confessional Issue for the Churches?, trans., David Lewis (Geneva: WCC Publications, 1987), 85-89. 
visi dan harapan masa depan; tempat di dalamnya korupsi, pencucian uang, polarisasi, fundamentalisme, dan penghancuran lingkungan merajalela. Tanah di dalamnya penguasa tanpa hentinya menyebarluaskan ketamakan/keserakahan. Sedangkan "tanah yang dijanjikan "adalah "domain kemuliaan" Allah (Yos. 24: 13-15). Kendati demikian, tanah yang dijanjikan itu lebih daripada sekadar lokasi geografis sebagai tujuan dan visi mengenai masa depan, yakni: sebuah tatanan ekonomi baru, sebuah masa depan eskatologis di dalamnya Allah memerintah atas segala sesuatu, termasuk kekuasan uang. Tanah terjanji adalah negeri masa depan di dalamnya Allah yang berinkarnasi di dalam Kristus itu memberlakukan keadilan, cinta, simpati, dan empati-Nya; tidak ada lagi ketamakan, individualisme, dan materialisme. Namun ziarah kita di tanah gersang belum berakhir.

Di tengah-tengah dunia seperti inilah, gereja-gereja dipanggil dan diutus dengan tiga tugas misiologis, yakni profetis, doksologis, dan praksis. Misi profetis terkait tugas kenabian, yakni memprotes setiap bentuk ketidakadilan dan keserakahan sistemik tanpa ragu sesuai tugas yang diamanatkan kepadanya. Misi doksologis mengacu kepada tugas mereformulasi serta mereinterpretasi ajaran dan pengakuan iman gereja tentang uang supaya lebih merefleksikan kemuliaan dan karya pembebasan Allah. Terakhir, misi praksis menunjuk kepada kepeloporan gereja dalam proses transformasi sosial, budaya, ekonomi, dan politik. ${ }^{39}$

\section{Masalah Kita di Indonesia}

Di Indonesia, kita sedang diperhadapkan dengan berbagai masalah serius. Masalah pertama dan paling menyita perhatian publik adalah korupsi. Meskipun korupsi, entah apa pun jenis dan motifnya, termasuk di dalamnya politik transaksional, adalah sebuah "kejahatan luar biasa" (extraordinary crime), akan tetapi korupsi sudah membudaya bahkan dilakukan oleh para pejabat yang beragama Kristen (warga jemaat). Lemahnya aparat penegak hukum di hadapan koruptor menyebabkan jenis kejahatan ini makin merajalela. Sementara itu, gereja diperhadapkan juga dengan upah buruh yang rendah, penjualan manusia (tenaga kerja) dan buruh migran, pelacuran, dan pemintaminta, semuanya demi uang. Bahkan, terkait masa depan segala ciptaan, gereja-gereja di Indonesia juga sedang diperhadapkan dengan

39 Schweiker, "Responsibility in the World of Mammon," 138-139. 
eksploitasi dan penghancuran ekologi yang dimotori oleh pemerintah dan aneka korporasi trans-nasional, multi-nasional, dan nasional yang mengakibatkan jutaan warga lokal tercabut dari akar historiskulturalnya. Semua ini didorong oleh roh ketamakan, demi uang yang setiap saat mengalir ke kantong kaum kapitalis.

Di kalangan internal gereja-gereja, kejahatan korupsi menjadi pemandangan sehari-hari kendati tidak sekentara korupsi oleh pejabat negara. Jenis kejahatan ini sering muncul melalui jual-beli jabatan gerejawi dengan "uang pelicin," pemberian dukungan politik gereja kepada calon tertentu dalam pemilihan pimpinan nasional dan daerah dan para anggota legislatif, barter pembangunan sarana ibadah dengan proyek tertentu, dan "doa politik" yang dibayar partai politik tentu supaya memenangkan pemungutan suara. Hak politik individu sebagai pemberian Allah direduksi kepada nilai nominal uang atau besaran upah yang diberikan kepadanya. Bahkan, pemanjaan nasabah oleh bank-bank pemerintah dan komersil dengan aneka fasilitas seperti kartu debit dan kartu kredit, kendati secara teknis memudahkan transaksi namun menyuburkan hasrat "gila belanja" dan gaya hidup hedonistik.

Di Jakarta dan beberapa kota besar lain di Indonesia, makin banyak pengusaha korporasional yang menjadikan gereja sebagai lahan investasi. Fenomena ini didasari oleh anggapan bahwa institusi gereja merupakan produsen "rahmat" yang tidak pernah merugi, yang senantiasa menghasilkan uang. Hakikat gereja serta ibadah menjadi semacam "kampanye Injil" untuk mengakumulasi uang demi dan atas nama kemuliaan Allah. Institusi gereja, meminjam Marx, diubah fungsinya sebagai "mesin uang" yang tidak pernah berhenti berproduksi: posisi uang berbanding lurus dengan seluruh aktivitas gerejawi. Uang dan perannya di dalam gereja, menggunakan ungkapan penulis kitab Ibrani, ibarat "pedang bermata dua" yang bisa meningkatkan kualitas hidup warga gereja, namun, serentak dengan itu, uang juga dapat menimbulkan perpecahan dan permusuhan antarwarga gereja bahkan antar-pemimpin gereja.

\section{Sebuah "Bahasa Baru” bagi Uang}

Agaknya tidak berlebihan jika "teologi uang" menjadi pertimbangan saya dalam tulisan ini. Alasan saya adalah karena sejauh ini uang beserta seluruh problematikanya belum dijadikan sebagai salah satu pokok penting di dalam ajaran (doktrin) gereja yang memberi perhatian serius bukan saja pada hakikat dan fungsi uang menurut Alkitab tetapi juga berbagai masalah yang ditimbulkannya. Kealpaan ini sangat ironis, karena hampir setiap saat kita diperhadapmukakan 
dengan masalah korupsi, perpecahan dalam jemaat, kemiskinan, dan kasus-kasus kriminal yang disebabkan oleh uang. Gereja secara kelembagaan, malah sibuk juga dengan mengumpulkan uang bagi pelayanannya.

Tidak adanya instrumen standar melalui kajian teologis yang cermat dan kritis menyebabkan penyelesaian masalah keuangan terjadi hanya pada tataran akibat, bukan akar persoalan yakni kurangnya pemahaman teologis jemaat tentang uang. Kenyataan yang sangat paradoksal adalah bahwa di satu pihak gereja berbicara tentang uang sebagai berkat Allah, namun, di lain pihak gereja dikesankan tidak mampu meyakinkan warganya bahwa korupsi adalah sebuah kejahatan. Malah dengan arogan, kalangan pemimpin gereja tertentu mengukur keberhasilan pelayanan berdasarkan jumlah uang dan aset yang dimiliki. Menyikapi masalah ini sebagian besar teolog menyadari akan betapa dilematisnya merumuskan sebuah teologi tentang uang. Namun bagi sebagian teolog yang merasa optimis, corak baru teologi ini bisa dirumuskan oleh gereja demi mencegah penyalahgunaan uang di dalam gereja dan masyarakat. Saya berpendapat bahwa jika pada masa kini uang semakin mendominasi seluruh dimensi kehidupan umat manusia bahkan membentuk serta mengorientasikan seluruh aktivitas keseharian maka praksis ekonomi gereja harus dimulai dengan sebuah "teologi uang."

Sehubungan dengan tanggung jawab inilah saya merujuk pada M. Douglas Meeks yang mengusulkan sebuah metafora baru bagi Allah. Fungsi metafora ini adalah menjelaskan hakikat dan seluruh tindakan Allah yang menentang penindasan dan ketidakadilan dalam dunia sebagai "rumah tangga publik." Metafora yang dimaksud adalah "Ekonom" yang dijelaskan dalam kerangka "teologi sebagai ekonomi." Jika metafora ini ditempatkan di dalam konteks percakapan tentang "uang" maka Allah adalah Pemilik uang. Konsekuensinya adalah uang harus dipahami sebagai berkat Allah karena secara material dibuat dari bahan baku ciptaan Allah. Allah sendiri yang memberi mandat, hikmat, dan pengetahuan itu kepada manusia sebagai mitra-Nya untuk menciptakan uang sebagai salah satu sarana dengannya nama Allah dimuliakan. Di dalam spektrum inilah, mandat untuk "menaklukkan" (Kej. 1: 28b) itu memperoleh makna positifnya, yakni supremasi uang dengan seluruh konsekuensinya harus ditaklukkan oleh manusia demi kebaikan bersama, bukan diberhalakan. Manusia harus menjadi subjek atas uang bukan menjadi hamba atau yang diperbudak. Implikasi dari metafora ini adalah setiap bahasa teologi tentang Allah sebagai "Ekonom" sejati harus menjadi "bahasa

40 M. Douglas Meeks, God the Economist: The Doctrine of God and Political Economy (Minneapolis: Fortress Press, 1989), 75-98. 
mesianisme humanistis" yang membebaskan di dalam sebuah horizon harapan masa depan bagi manusia bahkan seluruh ciptaan Allah."41

Ini berarti "uang" harus menjadi sebuah "bahasa baru" tentang Allah. Manusia bisa membuat, mencari, dan menggunakan uang karena Allah berkenan memberikan mandat itu. Uang tidak datang dengan sendirinya, malah tidak menciptakan diri sendiri. Uang adalah benda mati. Manusia dan sistemlah yang "menghidupkan" bahkan memberi legitimasi dan otoritas pada uang. Itulah sebabnya, perumpamaan Yesus tentang "uang yang hilang" (Luk. 15: 8-10) saya maknai sebagai "ketidakberadayaan uang menolong dirinya sendiri." Manusialah yang harus mencari dan memberi makna. Pencarian itu berhasil hanya karena kuasa Allah. Makna ini tentu harus berbeda dari "anak hilang" dalam pasal yang sama (Luk. 15: 11-32). Maksud saya, penderitaan dan kesengsaraan yang dialami sang anak adalah akibat dari ketamakannya sendiri. Pemberhalaan uang (entah sebagai kekuatan impersonal atau sebagai agama baru) inilah yang membuat sang anak bungsu terjerumus di dalam keterhinaan.

Namun, tidak seperti mata uang (dirham) yang harus dicari, manusia tetapi membutuhkan suatu kesadaran. Kesadaran akan indahnya hidup di rumah Bapa yang berkelimpahan, menikmati segala berkat dengan saling berbagi. Inilah yang harus ditanamkan sejak dini, sebab kehidupan kita di masa depan sama sekali tidak bergantung pada harta (bdk. Luk. 12:15). ${ }^{42}$ Kesadaran inilah yang menurut saya dapat menjadi sumber motivasi kita untuk kembali dari keterbuangan yang menyengsarakan itu ke dalam "rumah tangga Allah." Jika demikian maka tugas gereja-gereja adalah membangun kesadaran kritis akan uang sebagai berkat Allah, bukan sebagai Mamon yang didewakan sebagai penentu kehidupan dan masa depan. Di dalam spektrum pemahaman yang sama harus ditegaskan bahwa gereja-gereja memang tidak dapat melaksanakan pelayanan tanpa uang, namun uang bukanlah segala-galanya bagi gereja. Implikasinya adalah interpretasi gereja terhadap uang haruslah dilakukan dari dua arah. Dari sisi Ilahi, uang adalah berkat Allah melalui kerja, oleh karenanya uang memiliki makna spiritual. Dari sisi insani, manusia adalah pembuat uang sesuai mandat ilahi agar dengannya manusia dapat saling peduli serta memenuhi kebutuhan hidupnya.

Terkait dengan tanggung jawab gereja, harus ditegaskan bahwa semua orang Kristen dipanggil serta diberi mandat oleh Allah untuk menyelesaikan setiap masalah yang ditimbulkan uang, yakni meminimalkan kekuasan/dominasi uang yang secara sistemik 85-100.

${ }^{41}$ Rubem A. Alves, A Theology of Human Hope (Indiana: Abbey Press, 1975),

42 Ellul, Money and Power, 117-136. 
melenyapkan prinsip-prinsip fundamental kehidupan manusia. Gereja bisa melakukan tugas ini hanya apabila memiliki dan berpijak pada tindakan Allah yang membebaskan itu. Tugas kedua adalah gereja tidak boleh menjadi sama dengan dunia apalagi mengalah di hadapan kekuasaan uang. Menurut saya, sikap dan tindakan yang harus dilakukan oleh gereja adalah secara eksplisit memerangi cara-cara penggunaan uang yang menyengsarakan manusia beserta segenap ciptaan Allah. Pada posisi yang berlawanan, gereja harus menemukan kebenaran dan keadilan Allah yang sudah dan sementara ini ditenggelamkan oleh kekuasaan uang, yakni kebenaran sejati yang telah berinkarnasi di dalam Kristus. Tugas terakhir adalah gereja harus mewaspadai dan memerangi roh ketamakan yang berada di dalam dirinya sendiri, termasuk menjadikan uang dan kekayaan sebagai tujuan utama kehidupan. ${ }^{43}$

Pada tataran implementasi, saya mengusulkan dua alat ukur, yakni sumber dan motivasi. Sumber dan motivasi (tujuan) harus menjadi kriteria dasar untuk menilai apakah perolehan serta penggunaan uang sudah sesuai dengan kehendak Allah, sang Ekonom itu. Dua kriteria ini harus menjadi sarana pengujian kritis-teologis sekaligus penolakan atas klaim bahwa uang yang dipersembahkan kepada Tuhan, kendati sebagian kecil saja, dari hasil korupsi, penipuan, dan pemerasan itu pasti berkenan bagi Allah. Lebih ironis lagi, ketika gereja dipersepsikan oleh individu atau institusi koruptif sebagai "tempat pencucian uang" dengan dalih "toh hasil kejahatan korupsi pun dipakai untuk mendukung pelayanan." Karena itulah saya memandang penting "sumber dan motivasi" sebagai standar penilaian etis-moral bagi uang dan penggunaannya di dalam gereja sebagai sebuah institusi.

Sumber menujuk kepada "dari mana" uang itu diperoleh. Dengan cara penilaian ini seorang Kristen (apalagi pendeta dan perangkat majelis jemaat) memiliki ketegasan sikap yang dengannya ia mampu membedakan antara uang yang layak dipersembahkan kepada Allah dan yang tidak. Peristiwa Yesus mengusir para penukar uang dan pedagang hewan di Bait Allah (Yoh. 2: 13-25; bdk. Ams. 5: 21-23) adalah sebuah fakta biblis yang tak terbantahkan.

Motivasi menunjuk kepada "tujuan" memberi persembahan: Apakah sebagai wujud terima kasih kepada Allah atau meminta, membujuk, dan memaksa Allah agar membenarkan kejahatan korupsi? Fungsi dari kriterium kedua ini adalah menyadarkan manusia akan pernyataan biblis bahwa Allah sama sekali tidak bisa disuap apalagi didustai dengan memberi persembahan dari hasil korupsi untuk membenarkan tindakan mereka (Mal. 1: 6-16; 3: 6-9). Dengan

43 Ibid., 32-33. 
demikian, seluruh akibat yang ditimbulkan oleh "persembahan" itu (entah hasil pekerjaan atau ,penipuan, pemerasan, dan suap) menjadi tanggung jawab dari sang pemberi persembahan itu. Rahmat Allah sama sekali tidak bergantung pada seberapa kecil atau besarnya jumlah uang yang diberikan kepada Allah melainkan pada ketulusan dan kejujuran pribadi terhadap asal-usul serta motivasi pemberian kita (bdk. Luk. 21: 1-4).

\section{Penutup}

Di bagian akhir tulisan ini, saya menyampaikan sejumlah pokok pikiran sebagai kesimpulan.

Uang pada dirinya adalah netral. Namun ketika ia disalahgunakan pemiliknya, ia menjadi alat menciptakan keterasingan. Kekuatan uang terbukti menjadi sarana yang paling efektif dalam mereproduksi keterasingan manusia dari dirinya sendiri, dari sesama, dari pekerjaan, bahkan keterasingan dari Allah Pencipta. Semuanya ini tentu saja karena manusia memberi diri diperbudak dan dikendalikan oleh roh keserakahan.

Di masa kini, ketamakan telah menjadi sebuah ideologi baru yang menabrak kaidah-kaidah etis dan moral religius sekaligus mendekonstruksi sendi-sendi vital kehidupan individu dan komunitas global. Ketamakan dan pengejaran uang secara serampangan dengan membolehkan segala cara demi uang, kekayaan dan kehormatan, telah menciptakan polarisasi dalam masyarakat, menggiring jutaan orang kaya ke dalam sikap permusuhan, pengasingan diri, perendahan martabat, serta ketidakpedulian. Uang telah menjadi sebuah "agama baru" yang memiliki sangat banyak penganut melebihi agama-agama yang dilembagakan.

Sungguhpun demikian, uang juga merupakan sarana pelayanan antar-manusia. Bahkan Yesus, yang berasal dari masyarakat biasa, membutuhkan uang. Yesus, selama pelayanan-Nya, bergantung pada sumbangan para pendukung-Nya. Namun Yesus berbicara tentang bahaya uang dan kekayaan dan ucapan tersebut tidak boleh dimaknai sebagai "sikap anti-uang dan anti-kekayaan" melainkan menyangkut prioritas. Memiliki uang tidak salah, namun ketika uang disembah sehingga memperbudak pemiliknya, uang menjadi tuan yang bengis. Ucapan-ucapan Yesus yang bernada sarkastis bagi orang-orang kaya bukan berpusat pada uang dan harta mereka melainkan pada sikap serta cara penggunaannya.

Di dalam spektrum penegasan inilah gereja-gereja di Indonesia, seperti Kristus, juga harus bersikap kritis. Gereja dipanggil dan diutus untuk mewaspadai bahaya penyalahgunaan uang di dalam pelayanan. 
Supaya tidak terjebak di dalam kondisi seperti ini, tidak cukup bagi gereja hanya sekadar menyampaikan khotbah atau membuat seminar tentang bahaya menyalahgunaan uang. Tidak cukup bagi gereja-gereja mengklaim diri sebagai “anti-keterasingan.” Gereja-gereja institusional khususnya di Indonesia harus sungguh-sungguh membuktikan dirinya sebagai gereja-gereja yang tidak menciptakan keterasingan dengan warganya bahkan masyarakat di sekitarnya. Gereja perlu berkomitmen bahwa uang bukanlah tujuan akhir dari pelayanan. Jika gereja sungguhsungguh melayani Tuhan, maka berkat Tuhan itu melimpah tidak saja dalam bentuk uang, tetapi juga dalam cinta, ketulusan, kepedulian, kejujuran, serta persahabatan sebagai sebuah "bahasa baru" bagi uang sekaligus menjadi antitesis dari keterasingan.

\section{Tentang Penulis}

Nelman Asrianus Weny (lahir 1964) adalah seorang pendeta Gereja Masehi Injili di Timor (GMIT). Ia memperoleh gelar Sarjana Teologi (S.Th.) dari Fakultas Theologia Universitas Kristen Artha Wacana Kupang dengan skripsi tentang teolog Sri Lanka, Tissa Balasuria (1991) dan Magister Theologiae (2009) diperoleh dari Sekolah Tinggi Teologi (STT/STFT) Jakarta. Dengan beasiswa penuh dari GKI Pondok Indah Jakarta, ia melanjutkan studi dan meraih gelar Doktor Theologiae (2015) juga dari STT Jakarta dengan disertasi "Eschatologia Doloris: Sebuah Rekonstruksi Eskatologi Kristen berdasarkan Teologi Jürgen Moltmann, Mite Koreri, dan Filsafat Richard Kearney" dengan predikat cum laude. Minat utamanya adalah teologi sistematika/teologi konstruktf-kontekstual dan filsafat. Setelah menyelesaikan tugas sebagai "dosen tetap kontrak" pada Fakultas Teologi Universitas Kristen Satya Wacana, Salatiga, (2015-1017), ia menjadi dosen tetap di STT Gereja Methodist Indonesia di Bandar Baru, Sumatera Utara, sejak Januari 2018.

\section{Daftar Pustaka}

Alves, Rubem A. A Theology of Human Hope. Indiana: Abbey Press, 1975.

Boerma, Conrad. Dapatkah Orang Kaya Masuk Sorga? Terj., F.K.N. Harahap. Jakarta: BPK Gunung Mulia, 1999.

Bruce, F.F. "Render to Caesar." In Jesus and the Politics of His Day. Eds., Ernst Bammel and C.F.D. Moule, 249-264. Cambridge: Cambridge University Press, 1988.

Burrus, Virginia, and Catherine Keller, eds. Toward a Theology of Eros. New York: Fordham University Press, 2006. 
Costa, Mario. "For the Love of God: The Death of Desire and the Gift of Life." In Toward a Theology of Eros. Eds., Virgina Burrus and Catherine Keller, 38-62. New York: Fordham University Press, 2006.

Duchrow, Ulrich. Global Economy: A Confessional Issue for the Churches? Trans., David Lewis. Geneva: WCC Publications, 1987.

Ellul, Jacques. Money and Power. Trans., LaVonne Neff. Downers Grove, Illinois: InterVarsity Press, 1984.

France, R.T. Yesus Sang Radikal: Potret Manusia yang Disalibkan. Terj., P.G. Katoppo. Jakarta: BPK Gunung Mulia, 2004.

Gaay Fortman, Bas de, dan Berma Klein Goldenwijk. Allah dan Harta Benda. Terj., Bambang Subandrijo. Jakarta: BPK Gunung Mulia, 2001.

Galbraith, John Kenneth. Money. Boston: Houghton Mifflin, 1976.

Hardt, Michael, and Antonio Negri. Empire. Cambridge: Harvard University Press, 2001.

Hart, H.St.J. "The Coin of "Render Unto Caesar..." (a Note on Some Aspects of Mark. 12:13-17; Matt. 22:15-22; Luk. 20:20-26).” In Jesus and the Politics of His Day. Eds., Ernst Bammel and C.F.D. Moule, 241-248. Cambridge: Cambridge University Press, 1988.

Hinkelammert, Franz. "The Economic Roots of Idolatry." In The Idols of Death and the God of Life. Ed., Pablo Richard, 165-193. Maryknoll: Orbis Books, 1983.

Hixon, William F. It's Your Money. Toronto: COMER, 1997.

Horsley, Richard A. Jesus and the Spiral of Violence. Minneapolis: Fortress Press, 1993.

Kim, David, ed. Georg Simmel in Translation. Cambridge: Cambridge Scholar Press, 2006.

Kurtzman, Joel. The Death of Money. New York: Simon and Schuster, 1993.

Magnis-Suseno, Franz. Pemikiran Karl Marx: Dari Sosialisme Utopis ke Perselisihan Revisionisme. Jakarta: Gramedia, 2003.

Marx, Karl. Kapital: Buku 1 Proses Produksi Kapital. Terj., Oey Hay Djoen. Bandung: Hasta Mitra, 2004.

—. Kapital: Buku 2 Proses Sirkulasi Kapital. Terj., Oey Hay Djoen. Bandung: Hasta Mitra, 2007.

- Kapital: Buku 3 Proses Produksi Kapitalis Secara Menyeluruh. Terj., Oey Hay Djoen. Bandung: Hasta Mitra, 2007.

Meeks, M. Douglas. God the Economist: The Doctrine of God and Political Economy. Minneapolis: Fortress Press, 1989.

Mofid, Kamran. Globalisation for Common Good. London: ShepheardWalwyn, 2001. 
Moltmann, Jürgen. God for a Secular Society: The Public Relevance of Theology. Trans., M. Kohl. Lonon: SCM Press, 1999.

Outhwaite, William, ed. Kamus Lengkeap Pemikiran Sosial Modern. Terj., Tri Wibowo B.S. Jakarta: Kencana, 2008.

Pilgrim, Walter E. Good News to the Poor. Minneapolis, Minnesota: Augsburg Publishing House, 1981.

Rorty, Richard. Philosophy and Social Hope. London: Penguin Books, 1999.

Schacht, Richard. Alienasi: Pengantar Paling Komprehensif. Terj., Ikramullyah Mahyuddin. Bandung: Jalasutra, 2005.

Schweiker, William. "Responsibility in the World of Mammon." In God and Globalization 1. Eds., Max L. Stackhouse \& Peter J. Paris, 105-139. Harrisburg: Trinity International Press, 2000.

Simmel, Georg. The Philosophy of Money. Trans., David Frisby. New York: Routledge, 2004.

Sinaga, Martin, ed. A Common Word: Buddhists and Christians Engage Structural Greed. Minneapolis: Lutheran University Press, 2012.

Thoren, T.R, and R.F. Warner. Truth in Money. Ohio: Chagrin Falls, 1999.

Tillich, Paul J. Systematic Theology 2. Chicago: University of Chicago Press, 1957.

Weber, Max. The Protestant Ethics and the Spirit of Capitalism. Trans., Talcot Parsons. New York: Routledge, 1996.

Wills, Garry. What Jesus Meant: Maksud Yesus yang Sebenarnya. Terj., Semuel O. Aitonam. Jakarta: Gramedia Pustaka Utama, 2007.

Wojtyla, Karol. Love and Responsibility. Trans., H.T. Willetts. London: William Collins Son \& Co. Ltd., 1981.

Wolff, Jonathan. Mengapa Masih Relevan Membaca Marx Hari Ini? Terj., Yudhi Santosa. Jakarta: Gramedia, 2004. 